\title{
Problematika Akad Tijarah pada Produk Asuransi Pendidikan Mitra Iqra PT Asuransi Jiwa Bumiputra Syariah Cabang Jambi
}

\author{
M. Nazori Madjid \& Putri Alhidayah \\ Fakultas Ekonomi dan Bisnis Islam UIN Sulthan Thaha Saifuddin Jambi
}

\begin{abstract}
Abstrak: Penelitian ini untuk mengkaji problematika akad tijarah pada produk asuransi pendidikan Mitra Iqra PT. Asuransi Bumiputra Syariah Cabang Jambi. Penelitian menggunakan prosedur kualitatif, melalui metode observasi, wawancara dan dokumentasi, menemukan bahwa akad tijarah pada produk asuransi pendidikan Mitra Iqra PT. Asuransi Bumiputra Syariah Cabang Jambi belum sesuai dengan prinsip-prinsip syariah sebagaimana dimaksud dalam Fatwa Dewan Syariah Nasional Nomor 21/DSNMUI/X/2001 Tentang Pedoman Umum Asuransi Syariah, dan belum sesuai dengan Kompilasi Hukum Ekonomi Syariah (KHES) Pasal 564 ayat (1) dan (2). Dalam ayat (1) disebutkan, perusahaan asuransi (ta'min) selaku pemegang amanah wajib melakukan investasi dari dana yang terkumpul, ayat (2) investasi sebagaimana dalam ayat (1) wajib dilakukan sesuai dengan prinsip syariah. Akad tijarah produk asuransi pendidikan Mitra Iqra PT. Asuransi Bumiputra Syariah Cabang Jambi masih menjadi problema karena melakukan investasi kepada lembaga yang tidak berbasis syariah, sumber daya manusia yang kurang dalam memahami ekonomi syariah dan nasabah juga tidak mengetahui proses investasi tersebut.
\end{abstract}

Kata-kata kunci: akad tijarah; asuransi pendidikan; asuransi jiwa Bumiputera.

\section{Pendahuluan}

Asuransi merupakan metode untuk memelihara manusia dari berbagai macam resiko yang akan terjadi. Konsep asuransi merupakan konsep pertanggungan atau penjaminan. Disadari bahwa tidak semua orang di dunia ini memiliki tingkat ekonomi yang sempurna. Pada umumnya memiliki tingkat pendapatan yang menengah. Hasil pendapatan tersebut juga tergantung dari tingkat kebutuhan masing-masing individu.

Setiap orang memiliki tingkat kebutuhan yang berbeda-beda. Semakin tinggi tingkat kebutuhannya, maka semakin tinggi pula pengeluarannya. Namun, idealnya adalah kebutuhan harus disesuaikan terhadap tingkat income (pendapatan) yang seimbang. Maka, atas segala kemungkinan hal-hal resiko yang akan terjadi, sebaik mungkin manusia mencari konsep untuk dapat menanggulangi segala kerugian. ${ }^{1}$

Perbedaan mendasar antara asuransi konvensional dengan asuransi syariah, yaitu akad yang dilaksanakan pada asuransi syariah berdasarkan tolongmenolong (akad ta'awuni-yah), sedangkan pada asuransi konvensional

${ }^{1}$ Farid Fathony Ashal, Kedudukan Akad Tijarah dan Akad Tabarru' dalam Asuransi Syariah, Jurnal Human Falah, Volume 3. No. 2 Juli - Desember 2016, hlm. 238-239. 
berdasarkan pada akad jual beli. ${ }^{2}$ Akad yang terkandung pada asuransi syariah hakikatnya adalah perjanjian yang bersifat takaful yang bermakna saling memikul beban dan tolong menolong antar sesama umat. Sistem operasional asuransi syariah dibagi dalam dua akad, yaitu akad tijarah dan akad tabarru'.

Akad tijarah adalah akad antara peserta secara kolektif atau secara individu dan perusahaan dengan tujuan komersial. ${ }^{3}$ Menurut Muhammad Syakir Sula, dalam buku Asuransi Syariah, akad tijarah adalah akad peserta asuransi yang diinvestasikan sebagai dana tabungan peserta, yang kemudian wajib dikembalikan dan diserahkan kepada peserta. ${ }^{4}$

Akad yang dilakukan antara peserta dengan perusahaan sendiri terdiri atas akad tijarah dan akad tabarru'. Akad tijarah adalah semua bentuk akad yang dilakukan dengan tujuan komersial. Akad tabarru' adalah semua akad yang dilakukan dengan tujuan kebaikan dan tolong menolong, bukan semata tujuan komersial. Dalam akad tijarah (mudharabah), perusahaan bertindak sebagai mudharib pengelola dan peserta bertindak sebagai shahibul mal 'pemegang polis'. Jenis akad tijarah dapat diubah menjadi jenis akad tabarru' bila pihak yang tertahan haknya dengan rela melepaskan haknya sehingga menggugurkan kewajiban pihak yang belum menunaikan kewajibannya. Jenis akad tabarru' tidak dapat diubah menjadi jenis akad tijarah. ${ }^{5}$

Ada beberapa bentuk akad tijarah dalam praktek asuransi syariah, yaitu meliputi:

1. Akad mudharabah adalah akad yang melibatkan dua kelompok, yaitu pemilik modal (investor) yang mempercayakan modalnya kepada pengelola (mudharib) untuk digunakan dalam aktivitas perdagangan. ${ }^{6}$

2. Akad wakalah, yaitu Pelimpahan, pendelegasian wewenang atau kuasa dari pihak pertama kepada pihak kedua untuk melaksanakan sesuatu atas nama pihak pertama dan untuk kepentingan dan tanggung jawab sepenuhnya oleh pihak pertama. ${ }^{7}$

3. Akad wadiah yaitu dana terkumpul dari nasabah berupa premi dititipkan kepada perusahaan asuransi untuk dikelola atau dipelihara sebagaimana maksud akad. ${ }^{8}$

4. Akad musyarakah adalah akad antara dua pihak atau lebih dalam suatu usaha tertentu. Maksudnya adalah adanya keinginan para pihak yang bekerja sama untuk meningkatkan nilai asset yang mereka miliki secara bersama-sama. ${ }^{9}$

\footnotetext{
${ }^{2}$ Abdul Ghofur Anshori, Asuransi Syariah di Indonesia, Regulasi dan Operasionalisasinya di dalam Kerangka Hukum Positif di Indonesia, Yogyakarta: UII Press, 2007, hlm. 18-20.

3 Peraturan Menteri Keuangan No. 18/PMK.010/2010 tentang Penerapan Prinsip Dasar Penyelenggaraan Usaha Asuransi dan Reasuransi dengan Prinsip Syariah.

${ }^{4}$ Muhammad Syakir Sula, Asuransi Syariah: Konsep dan Sistem Operasional, Jakarta: Gema Insani Press, 2004, hlm. 177.

5 Ibid., hlm. 43.

${ }^{6}$ Ibid., hlm. 330.

${ }^{7}$ Ibid., hlm. 357.

8 Ibid., hlm. 356.

${ }_{9}^{9}$ Adiwarman A. Karim, Bank Syariah: Analisis Fiqh dan Keuangan, Jakarta: IIIT-Indonesia, 2003, hlm. 90.
} 
Konsep ini merupakan formula yang ditawarkan dalam asuransi syariah dalam menjalankan konsep pertanggungan atau penjaminan, dalam melepas dan mengeleminir unsur riba, maisir, dan gharar. Asuransi syariah merupakan bagian dari keuangan syariah. Keuangan syariah adalah bentuk keuangan yang dasarkan pada bangunan hukum Islam. Syariah artinya jalan menuju sumber air".10

Pihak perusahaan, dalam hal ini PT. Asuransi Bumiputra Syariah Cabang Jambi adalah sebagai pemegang amanah dari premi yang disetor para peserta asuransi syariah. Perusahaan selaku pemegang amanah membuat dua rekening berbeda dari premi tersebut, tijarah dan tabarru'. Adapun maksud akad tijarah, maka tabungan ini wajib diberikan kepada masing-masing peserta. Sementara pihak perusahaan akan mengelola kedua dana ini, bertujuan untuk diinvestasikan agar dapat meningkatkan dan mengembangkan dana tersebut yang selanjutnya akan menambah manfaat bagi peserta pada khususnya dan perusahaan. Dalam pembagian dana surplus selanjutnya menggunakan konsep mudharabah, yaitu membagikan hasil secara proporsional kepada pengelola (perusahaan Asuransi Syariah) dan kepada peserta (shahibul mal). ${ }^{11}$

Dalam akad asuransi sekurang-kurangnya disebutkan adalah:

1. Hak dan kewajiban peserta dan perusahaan.

2. Cara dan waktu pembayaran premi.

3. Jenis akad tijarah dan atau akad tabarru' serta syarat-syarat yang disepakati sesuai dengan jenis asuransi yang diakad. ${ }^{12}$

Penelitian Farid Fathony Ashal (2016) berawal dari permasalahan modelmodel akad bisnis selama ini seiring perkembangan zaman sesuai produk yang dikeluarkan variatif, sehingga sangat memungkinkan terjadinya unsur gharar, maisir, dan riba. Penelitian ini menemukan bahwa menemukan bahwa konsep kontrak yang diadopsi di Takaful di mana kontrak harus sesuai dengan fatwa DSN (Dewan Syariah Nasional) No. 21 dari Takaful. Menurut fatwa ini Takaful terdiri dari dua kontrak, kontrak tijarah dan 'kontrak tabarru. Kontrak kedua dianalisis dengan hadis yang melarang kontrak ganda dalam satu transaksi. Konsep multi akad dalam dalam asuransi syariah bertujuan untuk menjauhi dari riba, gharar, dan maisir. Multi akad yang terkandung dalam asuransi syariah bukanlah termasuk dari hadis rasulullah mengenai "bai'ataini fi bai'atin". Dalam hal ini perlu diperhatikan bagi kita semua, dalam memahami hadis untuk lebih jeli dan memahami konteks hadis tersebut. Hal ini untuk tidak mengkerdilkan makna dan maksud yang sebenarnya. Semoga tulisan ini dapat memberikan pemahaman dan dapat dikembangkan kembali untuk mencapati tahap kesempurnaan demi kemajuan industri keuangan syariah nasional.

Penelitian Tazkiah Ashfia (2015) berawal dari permasalahan yang diangkat adalah apakah terdapat ketidaksinkronan antara ketentuan ke empat dan ketentuan ke enam pada Fatwa DSN MUI No.21/DSN-MUI/X/2001 tentang Pedoman Umum Asuransi Syariah, serta bagaimana akad asuransi syariah yang

\footnotetext{
${ }^{10}$ M. Ma'ruf Abdullah, Manajemen Bisnis Syariah, Yogyakarta: Aswaja Pressindo, 2014, hlm. 175

${ }^{11}$ Farid Fathony Ashal, Kedudukan Akad Tijarah dan Akad Tabarru' dalam Asuransi Syariah, hlm. 249-250.

12 Muhammad Syakir Sula, Asuransi Syariah: Konsep dan Sistem Operasional, Jakarta: Gema Insani Press, 2004, hlm. 43.
} 
tepat dan memberi kepastian hukum. Hasil penelitian ini adalah kedua ketentuan yang terdapat dalam fatwa DSN Nomor 21/DSN-MUI/X/2001 tentang Pedoman Umum Asuransi Syariah tentang perubahan akad tabarru' ke akad tijarah masingmasing mempunyai dasar hukum. Namun, agar tidak terjadi keambiguan dalam memahami dua ketentuan tersebut, seharusnya dimasukkan frase terkait subjek yang terlibat dalam dua ketentuan tersebut agar lebih jelas. Pada ketentuan tentang akad tabarru' tidak dapat diubah menjadi akad tijarah, yang dimaksud di sini adalah ketentuan yang berlaku bagi peserta asuransi. Pada ketentuan dana premi tabarru' dapat diinvestasikan, maksudnya di sini adalah bahwa pihak perusahaan asuransi selaku pengelola dana premi tersebut dibolehkan untuk melakukan investasi di bidang-bidang dan dengan prosedur yang sesuai dengan ajaran Islam. ${ }^{13}$

Fenomena yang ditemukan di PT. Asuransi Bumiputra Syariah Cabang Jambi terkait dengan akad tijarah pada produk asuransi pendidikan mitra iqra adalah pengelolaan dana asuransi yang terkadang tidak diketahui nasabah dimana dana dikelola dan apakah sesuai syariah perusahaan pengelola dana tersebut. Pada awal perjanjian akan, pihak asuransi tidak memberitahukan tentang hal ini. Kondisi ini tentu menjadi kendala dalam pengembangan produk asuransi syariah. Kemudian jika merujuk Pedoman Umum Asuransi Syariah tentang perubahan akad tabarru' ke akad tijarah masing-masing mempunyai dasar hukum. Namun, masih terjadi keambiguan dalam memahami dua ketentuan tersebut, sebab tidak dimasukkan frase terkait subjek yang terlibat dalam dua ketentuan tersebut agar lebih jelas.

\section{Problematika Akad tijarah pada Produk Asuransi Pendidikan Mitra Iqra di PT. Asuransi Bumiputra Syariah Cabang Jambi}

Asuransi pendidikan mitra iqra adalah program asuransi dalam mata uang rupiah didasarkan pada syariah dan dirancang untuk memberikan perlindungan dan membiayai pendidikan bagi anak-anak, dari sekolah dasar hingga akhir pendidikan mereka (perguruan tinggi), baik dalam keadaan kedua orang tua masih hidup atau meninggal dunia berdasarkan syariah. Menariknya, keistimewaan dari produk ini, nasabah bisa menentukan besarnya iuran premi sesuai dengan kemampuan. Dan jika peserta memutuskan untuk menghentikan program, maka diberikan alternatif pilihan apakah mengambil uang tabungan beserta bagi hasilnya atau tetap melanjutkan proteksinya.

Menurut Ir. Nofiarman, Kepala PT. Asuransi Bumiputra Syariah Cabang Jambi mengatakan bahwa Anda dapat meningkatkan dana untuk pendidikan anak Anda sejak awal dengan menabung sebagian dari pendapatan Anda secara teratur. Kami siap untuk mengelolanya melalui program Mitra Iqra Bumiputera. Dengan Mitra Iqra, Anda bukan hanya mempersiapkan dana pendidikan, tetapi juga melindungi anak-anak Anda jika sesuatu hal yang tidak diinginkan terjadi sewaktu-waktu. ${ }^{14}$

13 Tazkiah Ashfia, Analisis Pengaturan Akad Tabarru' dan Akad Tijarah Pada Asuransi Syariah Menurut Fatwa DSN Nomor 21/DSN-MUI/X/2001 Tentang Pedoman Umum Asuransi Syariah, Jurnal Universitas Brawijaya Malang, 2014, hlm. 249-250.

14 Wawancara, Ir Nofiarman, 2 Juli 2018 
Asuransi pendididkan mitra iqra dirancang untuk memprogram pendidikan anak secara syariah mulai dari tingkat Taman Kanak-kanak sampai dengan anak menjadi Sarjana Strata 1 (S1), sekaligus berfungsi untuk menata kesejahteraan keluarga agar kelak apabila orang tua si anak meninggal dunia, anak tersebut pendidikan dan kesejahteraannya tidak akan terlantar atau terabaikan. Di bawah ini data nasabah asuransi mitra iqra' di Bumiputra Syariah Jambi:

Tabel 1 Jumlah Nasabah Produk Asuransi Pendidikan Mitra Iqra PT. Asuransi Bumiputra Syariah Cabang Jambi

\begin{tabular}{|l|l|l|}
\hline No & Tahun & Jumlah Nasabah \\
\hline 1 & 2012 & 5 \\
\hline 2. & 2013 & 21 \\
\hline 3. & 2014 & 159 \\
\hline 4. & 2015 & 221 \\
\hline 5. & 2016 & 458 \\
\hline 6. & 2017 & 442 \\
\hline 7. & 2018 & 366 \\
\hline & Jumlah & 1672 \\
\hline
\end{tabular}

Tabel di atas menjelaskan bahwa jumlah nasabah setiap tahun mengalami peningkatan, kecuali tahun 2017 menurun dibanding tahun sebelumnya. Wawancara dengan Sugar Dedi, salah satu nasabah AJB Bumiputera 1912 mengatakan bahwa: "Alhamdullilah, saya ikut asuransi pendidikan Bumiputera dan mengenai akad tijarah saya tidak tahu. Hanya saja setiap bisnis tentu berusaha mencari keuntungan."15

Di dalam asuransi pendidikan mitra iqra, peserta memiliki dua kemungkinan, yakni kemungkinan pertama, peserta hidup sampai masa kontrak berakhir, dan kemungkinan kedua, peserta meninggal dunia sebelum masa kontrak berakhir. Apabila peserta asuransi mitra iqra mengalami seperti kemungkinan pertama, yaitu hidup atau diberi umur panjang sampai masa kontrak berakhir dan pembayaran preminya lancar, maka pembayaran klaim yang berasal dari rekening tabungan peserta dan porsi bagi hasil, akan diterima oleh peserta yang bersangkutan kemudian digunakan untuk membiayai pendidikan anak. Akan tetapi apabila peserta mengalami kemungkinan yang kedua, yaitu meninggal dunia sebelum masa kontrak berakhir, maka pembayaran klaim berupa rekening tabungan peserta, porsi bagi hasil dan dana kebajikan yang diambil dari tabungan tabarru akan diterima oleh ahli warisnya untuk biaya pendidikan setelah ditinggal mati orang tuanya.

15 Wawancara, Sugar Dedi, 2 Juli 2018 
Adapun pelaksanaan asuransi pendidikan Mitra Iqra PT. Asuransi Bumiputra Syariah Cabang Jambi sebagai berikut:

1. Prosedur

Langkah-langkah yang dilakukan PT. Asuransi Bumiputra Syariah Cabang Jambi untuk memulai Mitra Iqra:

a. Pengisian Form SPAJ (Surat Pengajuan Asuransi Jiwa) dilengkapi kelengkapannya seperti fotocopy KTP, dan lain-lain.

b. Entry data peserta pada sistem.

c. Cetak Kuitansi Pembayaran.

d. Cetak Kuitansi Pembayaran Titipan Premi

e. Berikan Kuitansi Pembayaran Titipan premi kepada nasabah.

f. Kantor Cabang mengecek kebenaran Form Pengisian SPAJ.

g. Dari Kantor Cabang mengirim SPAJ (Surat Pengajuan Asuransi Jiwa) tersebut kekantor wilayah untuk mencetak polis.

h. Kantor wilayah memeriksa kembali dan mencetak polis.

i. Setelah polis jadi, polis dikirim kekantor cabang untuk diberikan ke pemegang polis Premi Mitra Iqra dihitung dengan rumus:

Manfaat Awal: Premi x Masa Asuransi Minimal Rp. 5.000.000,-16

2. Akad

Akad yaitu perpaduan antara penawaran (ijab) dan penerimaan yang merupakan suatu cara yang efektif untuk melakukan akuisisi terhadap kepemilikan dan pemindahan harta benda. Menurut Heri Firmansyah, SE, kepala tata usaha bahwa:

"Akad yang digunakan dalam asuransi pendidikan mitra iqra Bumiputera Syariah Cabang Jambi dalam pembagian keuntungan (tijarah) adalah akad bagi hasil (mudharabah) yang menggabungkan antara unsur tabungan dan unsur tolong menolong (ta'awun) yaitu tolong menolong pada sesama peserta asuransi."17

Ketika ada peserta yang terkena musibah (meninggal dunia), maka peserta lain akan ikut membantu dengan cara memberikan derma atau iuran kebajikan atau dana tabarru' kepada keluarga, seperti yang telah dialami oleh keluarga yang meninggal akan mendapatkan klaim dan manfaat asuransi. ${ }^{18}$

3. Premi

Premi adalah kewajiban pihak tertanggung kepada pihak penanggung yang berupa pembayaran uang dengan jumlah tertentu secara periodik. Pembayaran premi pada dasarnya adalah kewajiban pemegang polis, pembayaran bisa dilakukan dengan cara melalui, lewat agen, peserta langsung datang ke kantor asuransi, ataupun dikirim lewat rekening Bank yang telah ditunjuk. Premi dalam asuransi pendidikan mitra iqra Jambi terdiri dari:

Premi Tabarru' yaitu sejumlah premi yang dihibahkan oleh peserta (dana shadaqah, dana infaq) untuk saling tolong menolong (ta'awun) menanggulangi musibah kematian (risiko meninggal) di antara sesama peserta apabila ada yang meninggal dunia dalam masa asuransi.

Premi Tabungan adalah besarnya bagian premi setelah dikurangi premi tabarru dan premi biaya yang digunakan oleh perusahaan untuk diinvestasikan

16 Observasi, 2 Juli 2018

17 Wawancara, Heri Firmansyah, SE., 3 Juli 2018

18 Dokumentasi PT. Asuransi Bumiputra Syariah Cabang Jambi, 2018 
secara syariah dan hasil keuntungan dari investasi akan dibagi antara peserta (shahibul mal) dengan perusahaan (mudharib) dengan perbandingan keuntungan $70 \%$ untuk peserta dan 30\% untuk perusahaan asuransi.

Premi Biaya adalah sejumlah premi yang dialokasikan oleh peserta kepada mudharib/pengelola atau perusahaan untuk mengelola keuangan peserta agar aman, menguntungkan dan halal sehingga peserta tidak rugi. Premi yang harus disetor di asuransi pendidikan mitra iqra Jambi besarnya minimal Rp. 250.000,per triwulan sedang maksimalnya tidak terbatas. ${ }^{19}$

Cara perhitungan premi Mitra Iqra dihitung dengan rumus, yaitu: manfaat awal dan masa asuransi. Cara pembayaran premi Mitra Iqra bisa dilakukan dengan cara tahunan, semesteran, triwulan dan sekaligus yang terdiri dari premi tabungan, premi tabarru dan premi biaya.

a. Peserta yang masih hidup dengan peserta yang sudah meninggal memiliki manfaat produk Mitra Iqra yang berbeda sesuai dengan ketentuan yang berlaku.

b. Dalam perhitungan penerimaan manfaat asuransi terdapat perbedaan antara pembayaran yang dicicil (triwulan, semester atau tahunan) dengan pembayaran secara sekaligus. Pembayaran secara sekaligus lebih menguntungkan bagi nasabah atau pemegang polis manfaat asuransi Mitra Iqra' adalah: jika pihak yang diasuransikan hidup sampai akhir masa asuransi, maka anak yang ditunjuk sebagai penerima dana tahapan pendidikan akan menerima dana tahapan pendidikan.

Apabila pihak yang diasuransikan meninggal dunia dalam masa asuransi, maka peserta dibebaskan dari membayar kontribusi (premi) dan pihak yang ditunjuk akan menerima: a) Santunan kebajikan sebesar manfaat awal, b) Nilai Tunai, yang terdiri dari dana Investasi yang telah disetor dan bagi hasil (mudharabah) sebesar 70\% dari pengembangan dana investasi.

Menurut Heri Firmansyah, SE, sebagai karyawan PT. Asuransi Bumiputra Syariah Cabang Jambi mengatakan bahwa di asuransi pendidikan mitra iqra Jambi, premi peserta yang disetor ke perusahaan asuransi paling rendah Rp. 250.000,(dua ratus lima puluh ribu rupiah)/ tri wulan, dan paling tinggi Rp. 3.000.000,(tiga juta rupiah)/ tri wulan Dengan Manfaat Awal sebesar Rp. 204.000.000,dengan pengecekan kesehatan medical chek up (MDC), dengan masa kontrak 17 tahun. Bagi peserta yang ikut asuransi pendidikan mitra iqra di PT. Asuransi Bumiputra Syariah Cabang Jambi dengan manfaat awal sampai dengan Rp. 50.000.000,-(lima puluh juta rupiah), maka akan dilakukan pengecekan atau direcek oleh pihak supervisor, sedang sampai dengan Rp. 100.000.000,-(seratus juta rupiah) dilakukan pengecekan oleh Kepala Cabang dan yang besarnya diatas Rp. 100.000.000,-(seratus juta rupiah) pengecekan dilakukan oleh Kepala Wilayah, sedang di atas Rp. 1.000.000.000,- (satu milyar), pengecekan dilakukan oleh Kepala Devisi atau diwakilkan yang setingkat. ${ }^{20}$

${ }^{19}$ Dokumentasi PT. Asuransi Bumiputra Syariah Cabang Jambi, 2018 Lihat Refky Fielnanda,. Alternatif Perhitungan Return Shahibul Mal pada Skema Mudharabah Bank Syariah. Jurnal AnNahdhah 12.1 (2018).

20 Wawancara, Heri Firmansyah, SE., 3 Juli 2018 
Dan bagi peserta asuransi pendidikan mitra iqra yang panjang umur sampai berakhirnya akad, akan memperoleh dana tahapan pendidikan yang diberikan sesuai dengan jadwal yang telah tertera dalam Polis sebagai berikut:

a. Taman Kanak-kanak (TK) usia 4 tahun, peserta akan menerima 10\% x manfaat awal.

b. Sekolah Dasar (SD), usia 6 tahun, peserta menerima 10\% x manfaat awal.

c. Sekolah Lanjutan Tingkat Pertama (SLTP), usia 12 tahun, peserta akan menerima sebesar $20 \%$ x manfaat awal.

d. Sekolah Lanjutan Tingkat Atas (SMA) usia 15 tahun peserta akan menerima $25 \%$ x manfaat awal.

e. Perguruan Tinggi (PT.1), usia 18 tahun menerima 35\% x manfaat awal.

f. Perguruan Tinggi (PT.2) usia 19 tahun menerima Dana Tahapan Pendidikan $25 \%$ x sisa nilai tunai.

g. Perguruan Tinggi (PT.3) usia 20 tahun memperoleh $35 \%$ x sisa nilai tunai.

h. Perguruan Tinggi (PT.4) usia 21 tahun menerima 50\% x sisa nilai tunai.

i. Perguruan Tinggi (PT.5) usia 22 tahun menerima $100 \% \mathrm{x}$ sisa nilai tunai. ${ }^{21}$ Sedang bagi peserta yang meninggal dunia sebelum berakhirnya akad atau kontrak, peserta akan menerima dana sebagai berikut:

a. Santunan kebajikan.

b. Nilai Tunai (Premi tabungan + Mudharabah)

c. Dana Tahapan Pendidikan sebagai berikut:

1) Taman Kanak-kanak (TK) usia 4 tahun menerima 10\% x manfaat awal.

2) Sekolah Dasar (SD) usia 6 tahun menerima 10\% x manfaat awal.

3) Sekolah Lanjutan Pertama (SLTP) usia 12 tahun menerima 20\% x manfaat awal.

4) Sekolah Lanjutan Atas (SLTA) usia 15 tahun menerima 25\% x manfaat awal.

5) Perguruan Tinggi. 1 (PT.1) usia 18 tahun menerima 35\% x manfaat awal.

6) Perguruan Tinggi 2 (PT.2) usia 19 tahun menerima 15\% x manfaat awal.

7) Perguruan Tinggi 3 (PT.3) usia 20 tahun menerima 20\% x manfaat awal.

8) Perguruan Tinggi 4 (PT.4) usia 21 tahun menerima 20\% x manfaat awal.

9) Perguruan Tinggi 5 (PT.5) usia 22 tahun menerima $25 \%$ x manfaat awal. ${ }^{22}$

Dan apabila peserta berhenti sebelum akad berahir, maka peserta hanya bisa mengambil Nilai Tunai (Premi tabungan + Mudharabah) apabila masih ada.

Peserta boleh berhenti sementara (cuti) untuk membayar premi dengan syarat:

a. Apabila dalam rentang waktu atau masa cuti, ternyata peserta mendapatkan dana tahapan pendidikan, maka peserta wajib melunasi terlebih dahulu premi yang belum terbayar, baru kemudian bisa mendapatkan dan tahapan pendidikan.

b. Apabila peserta saat cuti bayar premi ternyata meninggal dunia, selama masih ada premi tabarru' maka:

1) Ahli waris menerima santunan kebajikan.

2) Nilai tunai (bila masih ada).

3) Dana tahapan pendidikan tidak berlaku. ${ }^{23}$

${ }^{21}$ Dokumentasi PT. Asuransi Bumiputra Syariah Cabang Jambi, 2018

22Dokumentasi PT. Asuransi Bumiputra Syariah Cabang Jambi, 2018

${ }^{23}$ Dokumentasi PT. Asuransi Bumiputra Syariah Cabang Jambi, 2018 


\section{Masa Kontrak}

Masa kontrak yang telah ditetapkan dalam asuransi pendidikan mitra iqra adalah minimal 2 tahun dan maksimal 17 tahun, dengan usia pemegang polis maupun peserta minimal 17 tahun, atau kurang dari 17 tahun tetapi sudah menikah. Sedang umur saat mulai asuransi ditambah masa asuransi maksimal 65 tahun. Sedang usia peserta non medical maksimal 53 tahun dan dalam kondisi sehat. ${ }^{24}$

Menurut Heri Firmansyah, SE, sebagai tata usaha PT. Asuransi Bumiputra Syariah Cabang Jambi mengatakan bahwa bagi peserta yang membayar langsung ke kantor, maka akan diberitahu langsung dan peserta diperintahkan untuk melengkapi data-data yang diperlukan, dan tidak sampai satu minggu dana tahapan bisa diterima. Kecuali peserta yang mutasi dari debit lain harus dilakukan pencocokan data dan konfirmasi lebih dulu, sehingga pambayarannya bisa terlambat. ${ }^{25}$

Dan apabila dana tahapan pendidikan terlambat diambil atau tidak diambil, maka dana tersebut oleh perusahaan dimasukkan ke utang piutang milik perusahaan sebagai dana titipan dan tidak ikut diinvestasikan, sehingga dana tersebut tidak memiliki keuntungan, (hal ini terjadi (tidak ikut diinvestasikan) karena memang seharusnya dana tersebut harus sudah dikeluarkan). Klaim (meninggal) dibayar dari rekening tabarru (dana kebajikan) dari seluruh peserta yang terkumpul, yang sejak awal sudah diikhlaskan oleh peserta untuk kesepakatan tolong menolong jika terjadi musibah pada salah satu anggota.

Perusahaan asuransi berhak untuk meminta diberikan dokumen-dokumen lain yang dianggap perlu dalam pengajuan klaim, dalam hal peserta meninggal dunia, jangka waktu pengajuan berikut bukti-bukti yang diperlukan selambatlambatnya 6 bulan sejak tanggal meninggal dunia.

\section{Mekanisme Pengelolaan Dana Mitra Iqra}

Peserta yang aktif melakukan pembayaran premi, mereka akan memperoleh dana tahapan pendidikan sebagaimana yang tertera di dalam polis. Menurut Ir. Nofiarman, Kepala PT. Asuransi Bumiputra Syariah Cabang Jambi mengatakan bahwa:

"Dalam asuransi pendidikan mitra iqra, akad atau perjanjian yang dipakai adalah akad atau perjanjian bagi hasil (mudharabah) dan wakalah yang merupakan bagian dari akad tijarah, dengan perbandingan keuntungan $70 \%$ untuk peserta asuransi, dan 30\% untuk perusahaan asuransi." 26

Ini sesuai dengan Pasal 562 Kompilasi Hukum Ekonomi Syariah) Berdasar kontrak bagi hasil (mudharabah) mekanisme pengelolaan dananya ada dua cara. Pertama pengelolaan dana yang memiliki unsur tabungan, dan kedua pengelolaan dana yang tidak memiliki unsur tabungan.

${ }^{24}$ Dokumentasi PT. Asuransi Bumiputra Syariah Cabang Jambi, 2018

25Wawancara, Heri Firmansyah, SE., 9 Juli 2018

26 Wawancara, Ir. Nofiarman, 9 Juli 2018 


\section{Akad tijarah pada Produk Asuransi Pendidikan Mitra Iqra di PT. Asuransi Bumiputra Syariah Cabang Jambi}

Akad tijarah pada Produk Asuransi Pendidikan Mitra Iqra di PT. Asuransi Bumiputra Syariah Cabang Jambi tidak sesuai syariah dikarenakan beberapa alasan sebagai berikut:

1. Pengelolaan Dana Investasi Oleh Unit Usaha yang Tidak Syariah

Asuransi Bumi Putra Syariah, merupakan anak cabang dari Asuransi Bumi Putra, yang kegiatannya diantaranya adalah memasarkan asuransi pendidikan mitra iqra. Mitra Iqra sendiri merupakan produk dari asuransi jiwa yang dirancang untuk memprogram pendidikan anak secara syariah mulai dari tingkat Taman Kanak-kanak sampai dengan anak menjadi Sarjana S1, sekaligus berfungsi untuk menata kesejahteraan keluarga agar kelak apabila orang tua meninggal tidak sampai kesejahteraan dan pendidikan anak terabaikan. Mitra iqra sendiri merupakan gabungan antara unsur tabungan dan unsur tolong menolong (ta'awun).

Dari hasil temuan tersebut diatas, ternyata dalam fatwa Dewan Syariah Nasional Nomor 21/DSN-MUI/X/2001, yang dijadikan dasar operasional asuransi syariah selama ini telah mewajibkan kepada perusahaan asuransi syariah, agar dan yang terkumpul dari para peserta diinvestasikan, dan investasi tersebut dilakukan sesuai dengan prinsip-prinsip syariah ${ }^{27}$, tetapi tidak ada sanksi bagi perusahaan asuransi yang tidak menginvestasi dana secara syariah, lagi pula sifatnya hanya fatwa Majelis Ulama Indonesia yang statusnya belum jelas dari sudut kelembagaan Negara, sehingga pelaksanaan asuransi pendidikan mitra iqra di asuransi Bumiputera syariah belum sesuai dengan prinsip syariah sebagaimana diatur dalam Kompilasi Hukum Ekonomi Syariah, sebab dana atau premi yang terkumpul dari para peserta asuransi pendidikan mitra iqra, oleh perusahaan asuransi dana tersebut dinvestasikan ke 21 perusahaan yang hampir kesemuanya masih konvensional, dan ini bertentangan dengan Kompilasi Hukum Ekonomi Syariah pasal 564 ayat (1) Perusahaan ta'min (asuransi) selaku pemegang amanah wajib melakukan investasi dari dana yang terkumpul, dan ayat (2) Investasi sebagaimana dalam ayat (1) wajib dilakukan sesuai dengan prinsip-prinsip syariah.

Menurut Ir. Nofiarman, kepala PT. Asuransi Bumiputra Syariah Cabang Jambi mengatakan bahwa:

Setelah dana tersebut terkumpul dari premi peserta asuransi pendidikan mitra iqra, maka dana tersebut, oleh kantor cabang akan disetorkan ke kantor wilayah yang berkedudukan di Jambi sebagai setoran, kemudian dari kantor wilayah cabang Jambi, dana tersebut selanjutnya dikirim ke devisi syariah (kantor pusat), dan dari devisi syariah dana tersebut selanjutnya dikirim ke departeman menejemen dana (sehingga dana tersebut bercampur menjadi satu antara dana yang berasal dari asuransi syariah dengan dana yang berasal dari asuransi konvensional), dan dari departemen menejemen. tersebut, kemudian oleh perusahaan asuransi Bumiputera dana tersebut direasuransikan ke Perusahaan

${ }^{27}$ Fatwa Dewan Syari'ah Nasional Nomor 21/DSN-MUI/X/2001 tentang Pedoman Umum Asuransi Syari'ah 
ReAs (Maskapai Reasuransi Indonesia), dan selanjutnya oleh Perusahaan ReAs (Maskapai Reasuransi Indonesia) dana tersebut diinvestasikan untuk bisnis ke 21 perusahaan."28

Dalam hal melakukan investasi, PT. Asuransi Bumiputra Syariah Cabang Jambi melakukan investasi belum sesuai ketentuan perundang-undangan, dan bertentangan dengan prinsip-prinsip syariah Islam. Di bawah ini ke 21 perusahaan yang belum sepenuhnya berbasis syariah, yaitu:
a. BNI Syariah
b. MANDIRI Syariah
c. BANK MEGA Syariah
d. PaninBANK Syariah
e. BANK bjb Syariah
f. BANKsyariah BUKOPIN
g. CIMB NIAGA syariah
h. BANK VICTORIA syariah
i. BAHANA
j. BNI Asset Management
k. Danareksa
1. MNC Asset Management
m. Insight INVESMENT
n. SAMUEL ASET MANAJEMEN
o. BP (BATAVIA PROSPERINDO)
p. PACIFIC ASSET MANAJEMENT
q. Trimegah Aset Manajemen
r. Lautandhana Investment Management
s. ReINDO (PT. REASURANSI INTERNASIONAL INDONESIA)
t. marein
u. NASIONAL RE (PT. REASURANSI NASIONAL INDONESIA). ${ }^{29}$

Menurut Edi Yanto, nasabah PT. Asuransi Bumiputra Syariah Cabang Jambi mengatakan bahwa: "Berkaitan dengan pengelolaan dana nasabah, maka kami tidak mendapat pemberitahuan mengenai hal itu. Kemudian saya tidak tahu apakah dikelola dengan syariah atau tidak dana tersebut."30

Menurut Sri Wahyuni, nasabah PT. Asuransi Bumiputra Syariah Cabang Jambi mengatakan bahwa: "saya juga tidak mengetahui lembaga yang mengelola dana asuransi saya syariah atau tidak." 31

Sedang dalam Kompilasi Hukum Ekonomi Syariah (KHES) Pasal 564 (1) Perusahaan ta'min (Asuransi) selaku pemegang amanah wajib melakukan investasi dari dana yang terkumpul. (2) Investasi sebagaimana dalam ayat (1) wajib dilakukan sesuai dengan prinsip syariah. Keputusan Fatwa Dewan Syariah Nasional Nomor 21/DSNMUI/X/2001, tentang Pedoman Umum Asuransi Syariah, bagian kedelapan, tentang Investasi, disebutkan pada angka (1) Perusahaan selaku

\footnotetext{
${ }^{28}$ Wawancara, Ir. Nofiarman, 9 Juli 2018

${ }^{29}$ Dokumentasi PT. Asuransi Bumiputra Syariah Cabang Jambi, 2018

30Wawancara, Edi Yanto, 9 Juli 2018

31Wawancara, Sri Wahyuni, 9 Juli 2018
} 
pemegang amanah wajib melakukan investasi dari dana yang terkumpul. (2) Investasi wajib dilakukan sesuai dengan syariah.

2. Kekurangan Tenaga Ahli yang Menguasai Bidang Ekonomi Syariah

Meskipun pengelolaan asuransi syariah telah ada peraturannya, walaupun masih sebatas Fatwa atau Kompilasi Hukum Ekonomi Syariah, Menurut Ir. Nofiarman, kepala PT. Asuransi Bumiputra Syariah Cabang Jambi mengatakan bahwa:

Namun di kalangan pengelola asuransi syariah ada kendala diantaranya Asuransi Bumiputera Syariah masih baru, kepengurusan yang masih satu antara yang syariah dan yang konvensional, masih kekurangan tenaga ahli yang menguasai bidang ekonomi syariah, juga pihak perusahaan AJB Bumiputera sendiri juga belum memiliki proyek atau lembaga yang mengurusi khusus syariah, sehingga akan lebih aman dan menguntungkan kalau dikelola sendiri. ${ }^{32}$

Perusahaan asuransi pendidikan mitra iqra Asuransi Bumiputera Syariah Jambi adalah perusahaan yang memberikan jasa dalam penanggulangan resiko yang dikaitkan dengan hidup atau meninggalnya seseorang yang dipertanggungkan. Sedang peserta asuransi pendidikan mitra iqra adalah perorangan yang mempertanggungkan jiwanya kepada pihak penanggung (perusahaan).

3. Ketidaktahuan Nasabah mengenai Pengelolaan Investasi Dana Asuransi

Dalam kegiatan asuransi pendidikan mitra iqra, pihak asuransi memberikan dana manfaat bagi pendidikan. Dimana pemegang polis berkewajiban membayar premi dan pihak perusahaan asuransi berkewajiban mengelola premi serta memberikan manfaat asuransi menurut ketentuan yang berlaku.

Menurut salah satu nasabah, Angela Winda L., S.Pt mengatakan bahwa: "saya tidak diberitahu mengenai pengelolaan dana asuransi, dan tidak tercantum pada klausul kontrak."33

Menurut Ir. Nofiarman, kepala PT. Asuransi Bumiputra Syariah Cabang Jambi mengatakan bahwa: "Pengelolaan dana asuransi Pendidikan mitra iqra tidak dijelaskan ke nasabah selama ini secara rinci." ${ }^{4}$ Meskipun AJB Bumiputera syariah telah mempunyai Dewan Pengawas Syariah yang bertugas diantaranya memastikan dan mengawasi kesesuaian kegiatan operasional sesuai dengan ketentuan-ketentuan dan prinsip-prinsip syariah yang dikeluarkan oleh Dewan Syariah Nasional, namun dari hasil penelitian ternyata pihak perusahaan AJB Bumiputera syariah dalam mengelola dana yang terkumpul dari para peserta asuransi pendidikan mitra iqra tidak melakukan sesuai dengan ketentuan dan prinsip syariah.

\section{Kesimpulan}

Dari pembahasan di atas dapat disimpulkan sebagai berikut bahwa: pertama, problematika akad tijarah pada produk asuransi pendidikan mitra iqra di PT. Asuransi Bumiputra Syariah Cabang Jambi belum sesuai dengan prinsip-prinsip syariah sebagaimana dimaksud dalam Fatwa Dewan Syariah Nasional Nomor

\footnotetext{
32Wawancara, Ir Nofiarman, 9 Juli 2018

33Wawancara, Angela Winda L., S.Pt., 2 Juli 2018

${ }^{34}$ Wawancara, Ir. Nofiarman, 9 Juli 2018
} 
21/DSN-MUI/X/2001 Tentang Pedoman Umum Asuransi Syariah dan Kompilasi Hukum Ekonomi Syariah (KHES) Pasal 564 ayat (1) dan (2). Dalam ayat (1) disebutkan, perusahaan asuransi (ta'min) selaku pemegang amanah wajib melakukan investasi dari dana yang terkumpul, ayat (2) investasi sebagaimana dalam ayat (1) wajib dilakukan sesuai dengan prinsip syariah. Kedua, Penyebab akad tijarah pada produk asuransi pendidikan mitra iqra di PT. Asuransi Bumiputra Syariah Cabang Jambi karena pengelolaan dana investasi dari asuransi kepada lembaga yang belum sepenuhnya berbasis syariah, sumber daya yang masih kurang dalam memahami ekonomi syariah dan nasabah tidak mengetahui hal itu. 


\section{BIBLIOGRAFI}

Anonim, Al-Quran dan Terjemahnya Bandung: Departemen Agama RI, 2007.

Abdul Ghofur Anshori, Asuransi Syariah di Indonesia, Regulasi dan Operasionalisasinya di dalam Kerangka Hukum Positif di Indonesia, Yogyakarta: UII Press, 2007.

Adiwarman A. Karim, Bank Syariah: Analisis Fiqh dan Keuangan. Jakarta: IIITIndonesia, 2003.

M. Ma'ruf Abdullah, Manajemen Bisnis Syariah, Yogyakarta: Aswaja Pressindo, 2014.

Muhammad Syakir Sula, Asuransi Syariah: Konsep dan Sistem Operasional, Jakarta: Gema Insani Press, 2004.

Fatwa Dewan Syari'ah Nasional No: 21/DSN-MUI/X/2001 Tentang Pedoman Umum Asuransi Syari'ah

Farid Fathony Ashal Kedudukan Akad Tijarah dan Akad Tabarru' dalam Asuransi Syariah. Jurnal Human Falah Volume 3. No. 2 Juli - Desember 2016.

Tazkiah Ashfia," Analisis Peraturan Akad Tabarru' dan Akad Tijarah Pada Asuransi Syariah Menurut Fatwa DSN Nomor 21/DSN-MUI/X/2001 Tentang Pedoman Umum Asuransi Syariah". Malang.

Peraturan Bank Indonesia Nomor 7/46/PBI/2005 tentang Akad Penghimpunan dan Penyaluran Dana Bagi Bank yang Melaksanakan Kegiatan Usaha Berdasarkan Prinsip Syariah

Peraturan Menteri Keuangan No. 18/PMK.010/2010 tentang Penerapan Prinsip Dasar Penyelenggaraan Usaha Asuransi dan Reasuransi dengan Prinsip Syariah.

Refky Fielnanda, Alternatif Perhitungan Return Shahibul Mal pada Skema Mudharabah Bank Syariah, Jurnal An-Nahdhah 12.1 (2018).

Undang-Undang No. 21 Tahun 2008 tentang Perbankan Syariah.

http://asuransisyariah.asia/product/4/94/Pengertian-Asuransi-Syariah. Di akses pada tanggal 18 Juli 2017

http://asuransimitraiqra.blogspot.com/diakses 13 Oktober 2018; pukul 11.34 WIB. 